(C) S. Mannia

\title{
MASKS AND CARNIVALS IN CONTEMPORARY SARDINIA
}

\begin{abstract}
The carnival occupies an important place in Sardinia, and attracts the attention of scholars with its continuously renewed meanings and functions. Furthermore, the institution of carnival is one of the cultural traits that has most oriented enhancement, research, re-proposal, revitalization of spontaneous groups and cultural associations: local traditions are re-learned and reworked along with specific identities and new forms of expression. In this sense, we can speak of new carnivals; cultural heritage in new economic and social contexts. In other words: today's representations and masks refer to an alleged tradition to respond to contemporary needs and requests. In the case of Sardinian carnivals, enhancement, recovery, re-proposal are usually spontaneous, endogenous processes, and they are, first of all, initiated to respond to «identity needs». The contribution tries to reflect on these issues, emphasizing the complexity of the carnival phenomenon in Sardinia.
\end{abstract}

Key words: masks, carnivals, cultural heritages, Sardinia

\section{Preliminary observations}

In the city of Romens, in 1580, the festivities of Candlemas and San Biagio decreed the beginning of the carnival. For 15 days, the town of Dauphiné became a popular theatre, a bustle of «parties, kingdoms, assemblies», the centre of masquerades, banquets, dances, games, races and processions, where the carnival of the rich, personified by Judge Guérin, coexists with that of the poor, personified by the popular leader Paumier, and where «the rites of life and death, of fruitful prosperity and death sentence cross each other in the microcosm of the [...] bustling city» (Le Roy Ladurie 1981: 215). This festive effervescence, based on inversions and excesses, tragically ends between $15^{\text {th }}$ and $16^{\text {th }}$ February, Monday and Shrove Tuesday, with the clash between the notables and commoners of Romens and the death of Paumier. Carnival is dead. This episode, in fact, closes the carnival celebrations prematurely. Shrove Tuesday will be «uncarnivalized» and it will bring «the very essence of an institution, which is based on conflicts, expulsions, assassinations (generally symbolic assassinations; but in this case, very real)» (ibid: 237).

Emmanuel Le Roy Ladurie investigates the uprising between city and countryside in the Dauphiné, between nobility-bourgeoisie and artisans-peasants, that is he analyses the carnival and its relations with the uprising. The carnival of Romens - a political-folkloric festival, as the French historian defines it - is in fact a carnival of protest which ends tragically emphasizing the class conflict. A hostility between alignments from which a dense web of folk symbols and

Mannia, Sebastiano - Professor of Cultural Anthropology and Ethnology and Methodology of Anthropological Research, Department of History, Human Sciences and Formation, University of Sassari (Italy, Via Zanfarino 62, 07100 Sassari). E-mail: smannia1@uniss.it 
codes emerges: the triumph of an initial chaos, disorder, which must be reconverted into cosmos, order. A carnival in which jokes and laughter, death and power are mixed.

The work of Le Roy Ladurie describes and analyses well the inversion and subversion, the mockery and the contestation, the trial and the execution of the carnival, namely some of the constitutive features of the carnival phenomena in the Mediterranean area ${ }^{1}$, and in particular in Sardinia, a region where different types of carnival can still be observed today. These features have various forms, outlining an articulated and complex picture: from the traditional anthropomorphic and zoomorphic masks of the mamuthones and issohadores from Mamoiada and the boes and merdules from Ottana, to the rediscovered carnivals of Orotelli, Fonni, Orani, Samugheo, etc.; from the carnival equestrian rides of Oristano and Santu Lussurgiu, to the parades of allegorical floats in various cities on the island ${ }^{2}$. Then there is another type of carnival characterized by a procession of people who, accompanied by music and songs and the declamation of satirical poems, brings in procession a donkey and a puppet impersonating carnival, namely the person responsible for all the community evils, who is tried, condemned, killed and eliminated in order to restore order $^{3}$. That is the case, for example, in Ovodda, Lodine, Gavoi, Tonara and in several other towns on the island (see Orrù 1999).

Therefore, the carnival occupies an important place in Sardinia, and attracts the attention of scholars with continuously renewed meanings and functions. Furthermore, the carnival institution is one of the cultural traits that has most oriented enhancement, research, re-proposal, revitalization of spontaneous groups and cultural associations ${ }^{4}$ : local traditions are re-learned and reworked along with specific identities and new forms of expression. In this sense, we can speak of new carnivals; cultural heritage in new economic and social contexts. In other words: today's representations and masks refer to an alleged tradition to respond to contemporary needs and requests. In the case of Sardinian carnivals, enhancement, recovery, re-proposal are usually spontaneous, endogenous processes, and they are, first of all, initiated to respond to «identity needs». The clash with contemporaneity inspires the search for identity and memories, which is indicative of the «collective need to find oneself in a past that gives the sense of cultural continuity precisely where on the contrary there has been discontinuity, violent uprooting, class leap. Searching for memories also means searching for an identity, which is also more to be built and rebuilt rather than to be found. And it should also mean achieving a perspective for the future» (Gallini 1977: 135).

${ }^{1}$ There is an impressive literature on the carnival. See for example: Bachtin 1979; Broccolini and Ballacchino 2016; Buttitta 1996; Caro Baroja 1989; Castelli and Grimaldi 1997 and 1999; Grimaldi 2003; Kezich 2015 and 2019; Mannia 2017a; Sisto and Totaro 2010 and 2014; Rossi and De Simone 1977; Sordi 1982; Testa 2014; Toschi 1955.

${ }^{2}$ On Sardinian carnivals, in addition to the references in the text, see: Alziator 1956 and 1957; Atzori 1988 and 1997; Atzori et al. 1989; Della Maria 1958a and 1958b; Mannia 2017a and 2020; Masala 1984 and 1987; Moretti 1954, 1963 and 1967; Orrù 1999; Satta 1982; Toschi 1955.

${ }^{3}$ Not all four phases are necessarily present (see Orrù 1999).

${ }^{4}$ Similar dynamics can be observed in numerous other contexts. Recently Giovanni Kezich pointed out that in Europe the carnival has «resurrected and made a comeback. In fact, ancient carnivals thrive more than ever, those that had been abandoned for decades or even centuries are revitalized and put back on the streets, and new ones are being created everywhere» (Kezich 2015: 19). There is an extensive literature on the phenomena of recovery, re-creation, re-invention of masks and carnivals. With regard to the Italian context, see, among others: Bonato 2006; Castelli and Grimaldi 1997 and 1999; Grimaldi 2001 and 2003; Mannia 2017b; Mirizzi 2012; Spera 2004. 
Carnival practices, in their plurality and complexity, have constituted one of the most representative and participated cultural institutions for traditional societies and it is also possible to seek in this sense one of the reasons for the growing vitality that the carnival phenomenon seems to have regained in recent decades. The economic and socio-cultural context has inevitably changed and with it the symbolic references and the ritual dynamics that, in the past, substantiated the festive moment. The latter, despite these phenomena of change, nevertheless continues to recur and re-identify the

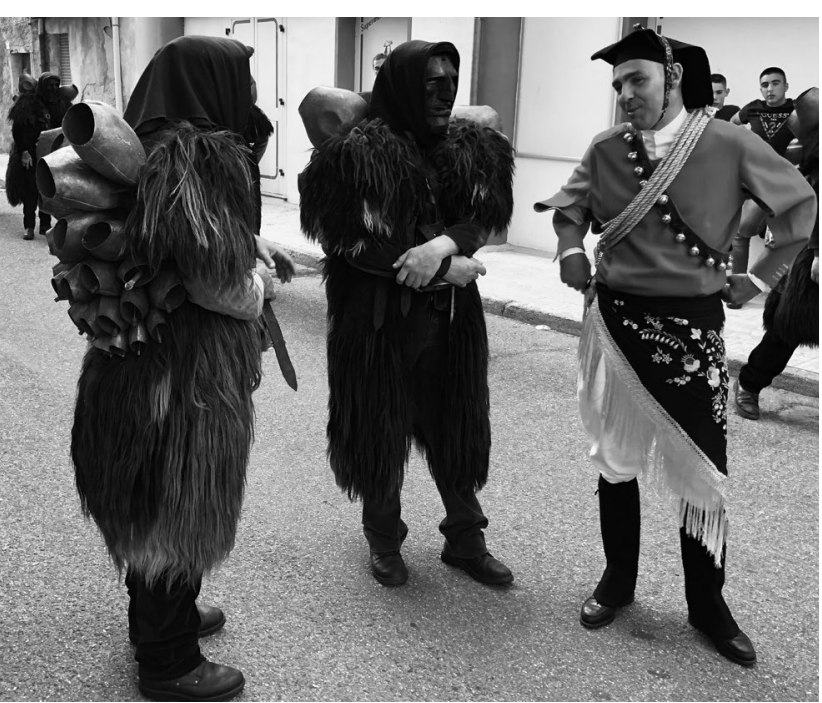

Мамуттонес и Иссокадорес в Мамойада. Фото С.Манниа. 2020 г. need for a celebration, thus contributing to re-establishing and re-functionalizing new and old calendars and allowing, at the same time, to re-propose and reaffirm the different individual and collective identities.

\section{Masks and carnivals in Sardinia}

Among the best known and most famous carnival masks and representations of Sardinia, we recall those from Mamoiada and Ottana which, although affected by important processes of change in the second half of the last century, are among the few cases that have not undergone an «interruption of tradition» ${ }^{1}$.

The mamuthones and the issohadores from Mamoiada make their debut on January $17^{\text {th }}$, sa prima issida, when they visit all the fires lit in the various districts of the town in honour of Saint Anthony the Abbot, making three laps around them. Mamuthones wear black sheepskins that cover their shirt, jacket, and trousers in velvet or moleskin. On their shoulders they carry sa carriga, a series of cowbells of various sizes held together with leather straps that can reach a weight of $30 \mathrm{~kg}$, while some bells fall on their chest. They also wear a brown or ruby red female handkerchief, a cap and a black anthropomorphic mask, sa visera, with a gloomy, tragic expression. The issohadores wear a white shirt, a red cloth bodice, a feminine embroidered shawl around the waist, white trousers in canvas or linen, gaiters, the traditional male headdress held with a colourful handkerchief around the face, a bandolier of cowbells and they carry a cane rope, sa soha. The members of the Pro Loco also wear a white mask, the use of which is contested by the other Mamoiada association, the Atzeni Association, which claims the historical non-existence of this mask ${ }^{2}$.

Mamuthones and issohadores stage a «dance procession»: the former arrange them-

${ }^{1}$ On the masks and carnivals in Mamoiada and Ottana see: Alziator 1955; Atzori 1997; Della Maria 1959; Marchi 1951; Masala F. 1955; Masala M. 1971; Massajoli 1972 and 1974; Satta 1982; Sordi 1993. For further reading: http://www.mamoiada.org/paese/mamuthones-issohadores/.

${ }^{2}$ Only the men from the community, members of one of the two associations, can be dressed as mamuthone e issohadore. 


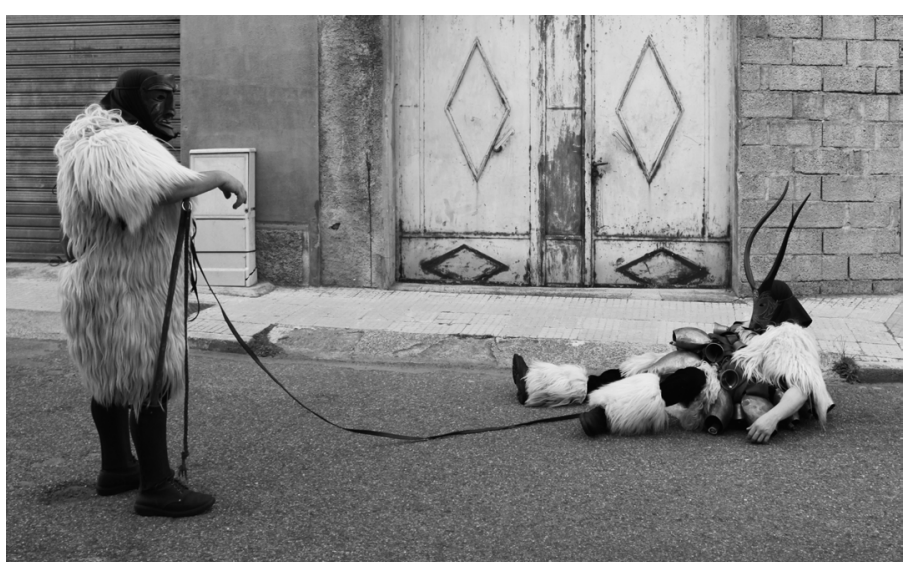

Бое и мердуле - персонажи карнавала в Оттана. Фото С.Манниа. 2019. selves in two parallel rows and following the orders of an issohadore advance mak some jumps towards the inside of the procession and others towards the outside. At a certain point, the driver makes a sign with his hand, the mamuthones continue to jump for a set number of times and at the end they perform sa doppia, that is, they jump in place three times in a row. Thus they continue throughout the course of the

event until the exhausting dance is completed: the $s$ 'issohadore leading the procession raises his hand, the mamuthones perform a few jumps and the guide spreads his arms to conclude; the mamuthones therefore jump again inwards and outwards, perform a $s a$ doppia and end the ritual with it.

The issohadores, in smaller numbers than the mamuthones, do not have a fixed position, apart from one that is in the centre between the two rows and, as mentioned, they dictate the rhythm of the entire dance; the others arrange themselves at the beginning and at the end of the procession. Their movements are graceful, their steps are light and accompany the heavy gait of the mamuthones. With a rope, as a sign of good luck, they capture the women in the audience.

The Mamoiada carnival ends on Shrove Tuesday with the death sentence of Juvanne Martis Sero. It is a straw puppet dressed in old clothes and with a funnel-like head - connected to a barrel - into which wine is poured and collected from the houses of the community. The puppet is carried on a cart richly decorated with flowers and branches usually pulled by a donkey while a group of men dressed in traditional female clothes and with blackened faces shout and lament in an allegorical way the figure of Juvanne Martis Sero. In the evening, the dying puppet is taken to a square and an attempt is made to revive him for the last time. But Juvanne Martis Sero will die, thus decreeing the end of the carnival.

In Ottana, the boes and merdules come out on January $16^{\text {th }}$, the eve of Saint Anthony the Abbot day, and they go around the fire lit in honour of the holy anchorite. The boes wear velvet jacket and trousers, white sheepskins, more rarely black, a bandolier with large cowbells, a black female handkerchief, white sheepskin leggings and a richly inlaid zoomorphic mask depicting an ox, sa carazza. The merdules also wear a mastruca and white sheepskin leggings (less frequently black) over a velvet suit, a black female handkerchief and a grinning anthropomorphic mask. They walk bent over, often supporting themselves with a stick, which also serves to try to keep the boes at bay, tied with a rope, sa soca. The boes are restless, they try to escape, kick, jump and mimic the charge towards any bystander, they lie down and wriggle while the merdules try to bring them back to order, often by beating them. Some merdules advance while playing a particular instrument, s'orriu, a cork cylinder closed at the top with a piece of animal skin tied with a thread soaked in pitch which produces a hoarse and dark sound when they rub it with their fingers. 
Other figures also participate in the Ottana carnival: the pig, the deer, the donkey and sa filonzana. The latter is represented by a male character wearing traditional black female clothes, men's leggings and boots and a black anthropomorphic mask with a pronounced grin. Sa Filonzana is old, hunched over and limping, she carries with her the spindle, the distaff and some large scissors hanging from her neck. During the pantomime, she spins the wool by threatening to sever the thread if the person she is addressing does not offer her a drink.

Both in Mamoiada and in Ottana, the carnival is one of the most awaited and participated celebrations and constitutes a strong identity marker, as well as an important cultural heritage, around which a significant tourism and economic network has been consolidated. It is precisely the identity dimension that has stimulated widespread processes of recovery and revival of the carnival tradition in recent decades. As a matter of fact, while from the second post-war period until at least the mid-1970s the models expressed by mass culture led individuals to reject and overcome «tradition», afterwards the complexity of the contemporary has led them to search for identities in customary cultural models and memories of the past. This research has been carried out by social actors far from the productive and the ideological aspects of the agro-pastoral world, and it has generated complex dynamics, within which festive events of various kinds have been revived, re-functionalized, and re-invented. In this general context, the carnival plays a central role: most of the masks and representations from the carnival on the island have been the object of recovery, revival and re-invention of tradition.

In 1979, in Orotelli, sos thurpos - the blind - make their comeback (Marchi, 1979; Pillonca, 1981), after the oblivion into which they fell in the years between the two world wars. The idea of recovering the local mask came from a teacher from Orotelli, who partnered with the «Salvatore Cambosu folkloric research group» and took the technical-scientific advice of Raffaello Marchi to ensure that her project followed a scientific method. The reconstruction of the Orotelli carnival was based on interviews with the elderly and on the notes of a local Canon, Salvatore Merche, who in the 1930s affirmed that local masks took «their name from the shape of their suit and were called mascaras de caddu, if they went on horseback, and mascaras de pè, if on foot. The latter were then called erithajos, tintinnajos, burrajos, thurpos, depending if they wore hedgehog skins, cowbells, bed covers or orbace cloaks ${ }^{1}$. They were also called cusinos and damas if they were dressed as gentlemen and ladies in costume: the latter two were gentle masks, while the others were amusement masks, except those on horseback» (Merche 1986: 37-38)2.

The thurpos performed for the first time on $11^{\text {th }}$ February 1979 and since then, together with the masks of Mamoiada and Ottana, they have represented the «triad of excellence» of the island's carnival, not only because they have been present in the folkloristic scene for decades - so much that we often tend to believe that the Orotelli mask, like the Mamoiada and Ottana ones, has a continuity of tradition - but also because carnivals have gained the interest of scholars.

\footnotetext{
${ }^{1}$ Orbace is a typical sheep wool cloth from Sardinia, it is very resistent and waterproof.

${ }^{2}$ Giuseppe Della Maria also mentions the mask of the thurpos in 1959 in an article relating to the masks of Ottana. Urging an informant on the Ottanese carnival, he wrote: «Are those your boes, joined in pairs by a lace tied around the waist, like Orotelli's sos turpos (literally, blind), also equipped with masks (not wooden, but cork) and rattles, wearing a gull with hood and accompanied, indeed, guided, by a third mask armed with a whip to be used by those who do not ... pay for a drink?» (1959: 7).
} 
The thurpos have faces blackened with soot and they wear, over their trousers and velvet jacket, a black orbace coat, su gabbanu, whose hood is pulled down below the forehead. They wear a neck strap from which several bells hang, s'otturada. The thurpos walk in pairs, like a yoke of oxen, guided and ruled by another thurpu by means of a rope tied at the waist. Some drag a plow, others mimic the sowing of wheat and there is also su thurpu-farrier who simulates the shoeing of oxen. Similarly to other Sardinian masks, some thurpos suddenly pounce on bystanders and imitate the behaviour of cattle, others, with sas sogas, capture some acquaintance forcing him to offer them a drink. On the last Sunday of Carnival, however, the thurpos themselves invite the audience.

Canon Merche, as noted above, indicated the existence of other masks from Orotelli: tintinnajos, burrajos and eritajos. The latter, which disappeared around the 1960s $-1970 \mathrm{~s}$, was recovered and re-proposed on the occasion of the Orotelli carnival in 1993. In this case as well, a writer and local scholar took care of the restoration and reconstruction of the mask, based on the stories of his great-grandfather and on the few notes left by Salvatore Merche. S'eritaju (the hedgedog hunter) wears a white robe with the hood pulled down over his face and his face is covered with a red handkerchief. He wears a leather necklace with cork disks covered with hedgehog skins. According to some old oral testimonies, s'eritaju, during the carnival, ran after women trying to hug them in order to prick their breasts with the quills of the collar.

The revival of island masks between the 1980s and 1990s began with the comeback of urthos and buttudos from Fonni, su bundu from Orani and s'urtzu, su 'omadore, sos mamutzones from Samugheo. S'urthu from Fonni wear sleeveless white sheepskin that also covers their head and legs. Their faces and arms are blackened with soot and are held together by chains joined to a piece of leather tied at the waist. During the pantomime, they climb on light poles, on the terraces of the houses, on trees, they throw themselves on the ground, kick, run, pounce on bystanders and especially on women trying to escape from sos buttudos, characters dressed in a long black orbace coat and a bandolier of cowbells, also with hands and face blackened with carbon black.

The first documents on the Fonni mask date back to the end of the nineteenth century: Pietro Nurra writes how the funeral lament given to the executed carnival puppet, Narcisu or Ecce Homo, was performed by buttudos, masks dressed «in rags, grotesquely tinged with soot on their faces, and they enjoy the greatest freedom in chasing and hugging girls, and in satirizing with verses. Mostly they go in groups, a widow with five or six daughters who bring their dead father, Narcisu or Ecce homo as they call him in Fonni, and from time to time, as they lay him on the ground, they let off steam in laments and songs [...]. As the improvisers warm up, the singing becomes licentious and obscene, and the chorus of the shouting people repeats the refrain at each verse: Coro meu!» (Nurra 1896: 69-70). Giuseppe Della Maria, in 1958, reported instead that «in Fonni, in rather recent times, during the carnival the buttudos (literally «ugly men, badly dressed»), equipped with cork masks depicting demons, appeared and dominated. They often had a beard made up of wool threads and several cowbells and rattles. The buttudos walked the streets of the town in groups, but, unlike the mamuttones, they were not accompanied by issoadores and their movement was governed by a rhythm that was clearly different from the one used in Mamoiada. Likewise, in Fonni there was another carnival custom. Men, among the tallest and most robust, disguised themselves as «bears», wearing cow and sheep skins and covering their faces with cork masks. They were chained by a «tamer» - in the typical 
island costume and cork mask - who let the «bears» free when common masked groups approached. Terrified, they hastily left» (Della Maria 1958a: 3-4)․

In Orani, the recreation of the local carnival was based on the testimonies of the town's elders and on an old model of a face mask kept at the Sardinian Ethnographic Museum in Nuoro. Su bundu, over his shirt, vest, trousers and leggings, wears su saccu, an orbace cape that completely covers the body, or otherwise an orbace coat with sleeves and a belt. Both the cape and the coat have a voluminous hood to which a large cork mask with long horns, nose and moustache is attached. Traditionally, the mask and nose are red while the horns, whiskers and chin are white. More recently, non-coloured natural cork masks are also used. Sos bundos also carry wooden pitchforks, sos trivutzos, with which they disturb the bystanders, sometimes drawing them in the pantomime.

More recently, another figure from the Orani carnival has been rediscovered, su maimone. He too wears a cork mask and has a fox fur on his head that falls on his back. He also wears goat skins and two hedgehog skins on his shoulders. On his back, he carries animal bones, while in his hand he has a stick, sa matzoca e punta, also lined with a hedgehog skin. Several documents were used for the reconstruction of su maimone. The first is a letter from 1955 written by the priest Raimondo Bonu that said: «The masks of Orani, as in the rest of Sardinia, are linked to the feast of St. Anthony in January, when the Sardinian carnival begins. Among the most significant, «Su Bundu» su fizu e su deus de su'entu (The son and the god of the wind); a figure between myth and history who represents good and evil. Dressed in black orbace, he represents evil. Dressed in white orbace he represents the good, with a cork mask handcrafted by expert artisans; in his hand «su furcone» a long stick. "Su maimone" the crazy mask dressed in boar, sheep, goat or calf skins with a cork mask similar to su "Bundu", on the shoulders a load of bones tied with dried intestines. They went around making the noise of the wind $»^{2}$. The second document is an alleged poem written in 1772 by Father Bonaventura Licheri, a Jesuit friar who, according to some scholars, visited the island to evangelize the populations still considered pagan along with Father Giovanni Battista Vassallo:

[...] Totus de ogni edade, faghen sos ballos tundos, che su 'entu sos Bundos, andan a muilos.

E non tenen acuilos, inghirian su fogu, sos meres de su logu, sunu bessidos.

De fresi sun bestidos, Nieddos e biancos, chintos in sos fiancos, cun sos batazos.

Chi sonan che sonazos, Bundos e Maimones, cun peddes de sirbones, 'ervegh' e 'igu.

Cun carazas de ortigu, Faghen sa 'oghe'e su 'entu, Suta su firmamentu, Sa pagania.

\footnotetext{
${ }^{1}$ Pietro Nurra, as we have seen, does not mention the s'urtzu mask. It should be pointed out that Nurra did not attend the Fonni carnival but he was interested in the improvisers who mourned the death of Narcisu in the last days of the carnival and he asked a group of people to stage the funeral pantomime. In line with Della Maria, however, Pietrina Moretti, who traces the disguises with animal skins and skulls and the use of zoomorphic masks to a widespread masquerade of the bear in numerous communities of Sardinia (1963), reported that the bear from Fonni was followed by sos buttudos, who wore a cork mask, discarded clothes and a belt with numerous bells (Moretti 1967: 28).

${ }^{1} \mathrm{http} / / /$ www.subundhu.it/il_gruppo/riferimenti_storici.php\#bonu - ultimo accesso 19.01.2017 ore 18:20.
} 


\section{$[\ldots]^{1}$}

The main masks of the Samugheo carnival are, as mentioned, the mamutzones, s'urtzu and su omadore. The former wear black or white goat skins and carry a leather structure on which several bells and cowbells hang and fall on the chest and on the back. Some walk with a stick, their faces are blackened with soot and they wear a cork headdress on their heads, also covered in skins, which leaves the face uncovered and on which goat horns are stuck. S'urtzu wears animal skins, he has a large cowbell hanging on his neck, his face is blackened with carbon black and his head is surmounted by the head of a goat complete with horns. Finally, su omadore wears a long black orbace coat, leather leggings, has a stick and a rope, sa soghitta, to tie s'urtzu. He too has a blackened face and carries a small pumpkin over his shoulder. While s'urtzu hops, limps, throws himself on the audience, throws himself on the ground and su omadore tries to bring him back to order, the mamutzones advance in hops, making the bells ring. Then s'urtzu is subjugated and thrown to the ground. At that point, one by one, the mamutzones take off their cork masks, put them back on the ground and continue to turn in a circular way. From time to time the mamutzones gore themselves, imitating the impetuous behaviour of the goats.

The alleged poem written by Bonaventura Licheri in 1772 also has some verses on the carnival of Samugheo and apparently sos mamutzones, in the past, were called sos ossudos:

[...] E in su fogulone / brincant inghiriados, / cun peddes cumbinados, / sunt sos

Ossudos.

Cun casiddos corrudos, / sambene pro caratza, / peddes de ogni ratza / che unu cunflitu.

Paret unu delitu / cun ossos in s'ischina, / ligados a istintina / faghent su ballu. [... $]^{2}$

The process of reconstruction of Sardinian masks has intensified exponentially in the last 20 years and has been accompanied by the publication, in 2005, of the poems by Father Bonaventura Licheri, which have played a fundamental role in the revival of several Sardinian carnivals. As a matter of fact, these poems have been used for the reconstruction of the masks and while some local scholars and various members of cultural and folkloristic associations do not doubt the presence of Bonaventura Licheri in the Sardinian masquerades, and consequently believe the Jesuit's poems to be reliable, others argue that the compositions have been written in recent times only to prove the existence of masks and carnivals that have long since disappeared and to support the process of recovery and reinvention ${ }^{3}$.

It is not possible here to dwell further on the reinvention process of Sardinian carnivals. There are more than 50 communities affected by the phenomena of carnival revival and, certainly, it is an analysis by default (Mannia 2017b).

${ }^{1}$ Everyone, no matter their age, do the Ballos Tundos (traditional Sardinian dance) like the wind the Bundhos (Bundos), they moan (bellow). And they have no limits, they surround the fire, the masters are driven away. They are dressed in black and white orbace clothes, knockers on their hips. They sound like rattles, Bundos and Maimones with boar, sheep and ox skins. With cork masks. They have the same voice as the wind, Under the stars, paganism. In http://www.subundhu.it/il_gruppo/ riferimenti_storici.php\#bonu - ultimo accesso 19.01.2017 ore 18:20.

${ }^{2}$ And in the bonfire they jump in circles, dressed in skins: they are sos Ossudos. With cylindrical cork vases adorned with horns, they have blood for a mask, skins of every race as in a conflict. It looks like a crime: with bones in their backs, tied by intestines, they do the dance. In http://www.mamoiada. org/_pdf/_mamuthiss/_Licheri2005.pdf - ultimo accesso 19.01.2017, ore 18:50.

${ }^{3}$ For furher analysis see Mannia $2017 \mathrm{~b}$. 
Among the carnival events on the island, the Sartiglia of Oristano is of particular interest. It is an equestrian carousel, which takes place on the last Sunday and the last Tuesday of Carnival. The horse race is configured as a test of skill that winds through the inner streets of the city, attracting thousands of visitors every year.

The Sunday Sartiglia is organized by the farmers' Gremio (corporation), placed under the protection of St. John the Baptist; the one Tuesday is prepared by the carpenters' Gremio, «protected» by St. Joseph.

On the day of Candlemas, the presidents of the two Gremi choose their respective componidori, the race leader. From this moment on, preparations are frantic, including the control of the clothing of su componidori, whose dressing, both on Sunday and Tuesday, is one of the central moments of the entire event. The componidori seats on chair on a table sprinkled with wheat and flowers. A woman, sa massaia manna, and two girls, sas massaieddas, dressed in traditional clothes will be charged of helping him getting dressed.

Su componidori wears a white shirt, a leather jacket, honey-coloured trousers, boots, and a belt on the hips. The sleeves of the shirt are closed with ribbons and tapes: the ones distinguishing the Gremio of the peasants are red, those characterizing the Gremio of the carpenters are turquoise and pink. The closure of the jacket is also different: the one of $s u$ componidori of the peasants is fastened on the front with strips of leather, the one of $s u$ componidori of the carpenters is closed with heart-shaped silver studs. The robing ceremony ends with an embroidered white veil that descends from the head to the shoulders, an androgynous mask - earth-coloured for the peasants, lighter for carpenters - and a cylinder. All the phases are accompanied by the rolling of the drums and, once the robing is finished, they bring in a horse for su componidori. The animal is brought close to the table and from this moment the rider can no longer touch the ground until the end of the event. The president of the Gremio hands out a bouquet of periwinkle and violets, sa pipia 'e maju to su componidori, with which he blesses the bystanders from the horse. Thus begins the Sartiglia: first su componidori and then the other riders chosen by him, including su secundu and $s u$ terzu (lit. the second and third, i.e. those who make up the triad with the leader), launch the galloping horses and with a sword they try to pierce a star hanging from a thread stretched along the path. After this first challenge, the president of the Gremio gives the componidori the stocco - a wooden sword, with which the skill test is repeated (a test reserved only to the trio). The more stars you manage to skewer the more prosperous the year will be.

The carousel ends with sa remada: the componidori, lying on his horse, spurs the animal to a gallop and blesses the Gremio and the audience. This phase introduces the pariglie, that is the acrobatics on horseback of the riders who took part in the Sartiglia shortly before, and this is also concluded by the componidori and his secundu and terzu who perform another remada. Lying on his horse, he blesses the audience with sa pipia 'e maju while the horses are galloping, then he reaches the other riders who greet him with a thunderous applause while he continues to bless the bystanders.

In Sardinia, carnival events generally end on Shrove Tuesday. An interesting exception is the Ovodda carnival which ends on Ash Wednesday, Su Mercuris de Lessia. Those who participate in the carnival ritual blacken their faces with burnt cork soot and pour into the streets of the town mingling with the audience. It is a transgressive carnival, without rules, which involves an excessive consumption of alcohol, dances and songs and the derision of the puppet Don Conte, who is transported on a cart pulled by a donkey through the streets of Ovodda. Don Conte is made with old rags, he usually has male features and pronounced 
genitals. On Ash Wednesday, Don Conte is tried, condemned to the stake and thrown from a bridge on the outskirts of the town.

The Ovodda carnival expresses the disapproval of facts not accepted by the community, subsumes the desecration of authority, the contestation of power, through the condemnation and elimination of the puppet, a process that can be documented, with different ritual practices depending on the context, also in Gavoi with Zizzarrone, in Tonara with Coli Coli, in Lodine with Su Ziomo, in Olzai with Juvanne Martis Sero, in Fonni with Narcisu or Ce homo. And this leads back to the classic interpretations of the carnival as an agrarian ritual in which the elimination of evil is necessary for the propitiation of good.

In Bosa as well the carnival, one of the most transgressive on the island, ends with the burning of the Giolzi after long celebrations involving the entire community. The centrepiece of the Bosa carnival is Shrove Tuesday, when the participants wear old and dark women's clothes, blacken their faces and carry in their arms or on a wheelbarrow a dismembered puppet with its genitals in evidence. The masked participants perform satirical funeral lamentations, s'attittidu, with sexual allusions and try to attract the attention of the onlookers to the puppet, asking unu tikkirigheddu de latte (a little milk) to refresh the child who has been abandoned by his mother devoted to carnival frolicking. Sexual references are central to the Bosa carnival representation, which exalts subversion, licentiousness, freedom.

In the evening, the masked participants wear white clothes, usually sheets, and their blackened faces are covered with a pillowcase. Holding a lantern or a candle, they run through the streets of Bosa, illuminating the genitals of the people who approach them. Afterwards, they prepare the stake for the Giolzi, puppets of straw and rags dressed in torn clothes or barrels of wine coated in rags as well. The various puppets are gathered, tried and burned at the stake.

Between the two phases of the Bosa carnival there is the parade of allegorical floats that mocks and criticizes themes and characters connected to political and social issues, both locally and nationally, through the declamation of irreverent satirical poems. In this sense, the Bosa carnival represents an exemplary case of political and social criticism and condemnation that still expresses the cultural institutionalization of an extraordinary, exceptional disorder, however controlled and regulated by specific rules imposing well-defined behaviours. It is a carnival that has managed to institutionalize, and therefore to control, social reprobation through sarcastic and irreverent songs, thus becoming an instrument through «which popular protest against «authority» and «power» generally turns into political denunciation» (Atzori 1978: 5).

In Tempio Pausania the parade of floats and King George burning on the stake are the central moments of the most impressive and famous allegorical carnival on the island. King George, formerly called Gjolgju Puntogliu, is a papier-mâché puppet seated on the throne symbolizing power, authority. Starting from Fat Thursday he attracts all the attention and honours of the people: he goes to the city with his court and his ambassadors in search of Mannena, his future wife. The wedding is celebrated on Sunday but already on Shrove Tuesday, in the late afternoon, the King is accused of a whole series of misdeeds committed during the year, and among these he is guilty of having corrupted Mannena first marrying her and then getting her pregnant during the carnival celebrations. For these reasons King George is sentenced to death: the will is read and finally burned at the stake amidst allegorical cries and tears. The King dies leaving behind an heir, Mannena's son, who will play King George in the next carnival. 


\section{Final remarks}

«Carnival is dead; it is dead, and not to be resurrected year after year, as was once the case. It was an old-fashioned celebration. And today what is most important to us is above all to be modern. Religious people believe that, as a remnant of paganism, it is dead and it should remain so; in fact, not even the rationalists like carnival very much. However, it was neither religious fervour nor the activism of the "left" that decreed its extinction, but rather the affirmation of a concept of life that is neither pagan nor anti-Christian, but more simply secularized, a bureaucratic secularism whose origin dates back to several decades ago» (Caro Baroja 1989: 19 [1965]).

This is what Julio Caro Baroja wrote in the mid-1960s. It was a period of extensive economic, social and cultural transformations, which, in several European regions, saw traditional carnival performances decline or disappear completely. Only a few years later, this decline was indeed followed by a progressive, controversial and uneven effort to recover, recreate and reinvent masks and representations. The Spanish scholar, in fact, was among the first to research the reasons for the resurrection of the carnival, but also of its eclipse.

Today it is widely proven that the deconstruction of the traditional agro-pastoral economy - at least in the Mediterranean area - and the consequent change in the ideological references of the societies that based their «existence in the world» on the intervention of transcendent forces have had a decisive influence on the disappearance or on the redefinition of numerous ceremonial events and primarily of carnival phenomena.

Ever since the 1970s, the Carnival has always come back to life. From that moment, there has been an ever-growing need for a «return to tradition» and, therefore, a greater demand for festive experiences rooted in the past: «The old ritual and symbolic apparatuses, [...] liberated from greater constraints of tradition as a result of the disintegrating processes, can now assume new values and respond to different needs in their initially unexpected revival» (Bravo 2003: 35). Popular traditions prove to be, on a community level, the most effective means of dealing with the phenomena of globalization and, more than any other ceremonial event with a certain religious dimension, the carnival has been largely used in processes of rediscovery and invention of a new identity, but also from the point of view of tourism. There are several communities that rediscover and re-propose the carnival every year, often imitating masks and representations already recovered elsewhere in a process of emulation which in some areas, for example in Sardinia, has consolidated roots. Pro loco, tourism institutions, cultural and folkloristic associations, municipalities, patrons and sponsors have long been at the centre of the carnival revival and many carnivals depend on public funding. It is a very common practice, especially when a carnival representation acquires a certain fame, «to do everything possible to launch it into the tourist production and consumption channels. In other words, you want people to enjoy your Carnival but you also want to sell and make a good profit out of it. It goes without saying that in the past there was no possibility of drawing on public sources of funding, and the Carnival was only consumed and enjoyed, but it could not be sold» (Orrù 1999: 31).

In Sardinia, but also in other regions, the enhancement and revival of masks and carnivals have marked the re-birth of this specific festive moment. For instance, in reference to animal disguises, Piercarlo Grimaldi has recently observed that the recovery of the carnival theme is the last «unprecedented cultural process of a reawakening of interest on the part of contemporary, postmodern society» (Grimaldi 2012: 140) - a «symbolic re-wildening» that can be recorded in different areas of the Peninsula. But in my opin- 
ion it is should also be noted that in recent years, with the spreading on a local level of a more or less defined idea of »heritage» (in this regard, see the recent issues, 28-29 and 37-39, of Museum Anthropology), we are witnessing a 'further and new phase of re-elaboration and re-semantization of the carnival. The rediscovery and revival of masks and representations is accompanied in an increasingly defined way by the need for Pro Loco, cultural associations and folkloristic groups to distinguish, to protect their carnival from this uncontrollable flourishing of carnival practices. In many communities, the carnival is assumed and represented in terms of cultural heritage by local institutions and administrations, probably influenced by the contemporary anthropological research. Mamuthones and issohadores from Mamoiada, the Sartiglia of Oristano, the Carrasciali Timpiesu are just a few examples of how the community identifies itself with its own carnival and of how it is recognized from the outside for its carnival. For these reasons, the need to capitalize and certify tradition strongly emerges, within a dialectic of political demands, identity needs, passions and cultural affiliations, and economic interests. A process that inspires even more the search for carnivals, their recognition and their protection and enhancement, also through the creation of brands. This happened recently in Sardinia, where some regional councillors presented a draft law (n. 400 / 27.02.2017) in order to establish a «Regional Register of Traditional Masks of Sardinia» and a Scientific Committee at the Regional Superior Institute for Ethnographic (ISRE), as well as to establish general rules on how to register masks and on the issue of the Trademark of Tradition. The draft's authors write: «The ancestral anthropomorphic and zoomorphic masks refer to the millennial history of Sardinia and evoke with their symbolism mysterious, ceremonial rites, propitiatory dances and a close relationship between a man and the earth. Often these masks, bearers of a history that is long forgotten, cross the boundaries of regional knowledge and with their strong symbolic value and the aura of mystery that surrounds them, they are part of the representation of the immense cultural heritage that our land still cherishes». An «invaluable wealth», a «cultural legacy» to be protected and valued with «common sense» and «scientific rigor», preserving it through the law «from the pressure of modernization» and «a certain way of inventing and recovering masks and traditions for the only folkloristic consumption which, without serious, transparent and convincing origins and without the slightest scientific confirmation, in the long run will generate confusion, create cultural and financial damage». The draft law allows that a community can oppose the request for registration of an identical or similar mask from another municipality, a measure that also extends to the adoption of an identical or similar name. Municipalities have «the right to make exclusive use of the mask for the benefit of their own community, including through the authorization of use by third parties who are an expression of that community». The proposal of the Councillors, embellished with identity poetics, stereotypes and representations, effectively outlines the probable near future of numerous ceremonial events and in particular the change that has led from the elaboration, management and use of a cultural expression by a community to its management by local associations and finally to its administration by institutions, which combine the need for protection and enhancement with tourism and economic requests.

Similarly, the draft law n. 189 was presented on March $15^{\text {th }}, 2013$ to the Senate of the Republic, to guarantee "constant and certain" funding for carnivals that have national and international importance. In particular: $50 \%$ of the resources would go to the Viareggio Carnival Foundation, while the remaining 50\% should be divided among the other nation- 
ally renowned carnival events, no more than eight. The Ministry of Cultural Heritage and Activities and Tourism assigns annual funding for «historical carnival events», in order to «recognize their historical and cultural value in the context of the Italian Tradition and their potential to implement the attractiveness and competitiveness of local tourism». The recipients of this contribution include the Carnival of Viareggio, Venice, Ivrea, Putignano, Oristano, Mamoiada, Tricarico, etc.

A further step in the process of institutionalizing the tradition is the request for registration in the Representative List of the Intangible Cultural Heritage of Humanity. For example, the carnival of Binche in Belgium (2008), the carnival of Oruro in Bolivia (2008), the carnival of El Callao in Venezuela (2016), the carnival of Granville in France (2016) are already registered. The Surova Festival in Pernik, Bulgaria, which was incuded in the List in 2015, celebrates the New Year with masked processions: Kukeri and Survakari.

Distinction, protection and enhancement with respect to other masks and representations, therefore, are the principles followed by groups and associations and for these reasons the inclusion in the representative list of UNESCO is supported by a growing number of communities. It is the maximum degree of institutionalization of a festive phenomenon that boasts the recognition of an international powerful institution, but at the same time it reveals an evident paradox, since «despite the concerns and appeals of UNESCO for the safeguarding of its cultural heritage, they trigger and produce both material and symbolic changes in that same heritage» (Testa 2014: 419).

The carnival period no longer actualizes the deep connection between masks and the dead, between the chthonic dimension and the rebirth of nature and therefore of life, between the renewal of time and New Year's celebrations. Today's carnivals are despatialized and decalendarized, that is the sacred space-time in which the carnival performances originated has become a showcase that can attract the audience depending on personal tastes. Carnival masks and rites respond to the new needs and anxieties of contemporary man, they are inscribed with new meanings within the local ceremonial calendars, taking root in the community identity. The traditional carnivals have been re-functionalized and institutionalized and they have thus become «an authentic symbol of post-modernity» (Buttitta 2010: 248), «the oxymoron of a new-born ancient celebration» (Clemente 1997: 101). Certainly, even today's carnivals, beyond these new connotations, continue to subsume in the contemporary the time of the extraordinary transgression, representation and improvisation, and for these reasons a new time is coming for carnivals, with new symbols, new meanings, new ritual codes, new needs.

\section{References}

Alziator, F. 1955. Bucrani e mimi ottanesi [Octane bucrani and mimes]. «Cagliari Economica» 9: 3-8. Alziator, F. 1956. Presupposti allo studio del Carnevale sardo [Prerequisites for the study of the Sardinian Carnival]. «Lares» XXII: 49-55.

Alziator, F. 1957. Il folklore sardo [Sardinian folklore]. Cagliari: La Zattera.

Atzori, M. 1978. Potere e ideologia: spettacolo e contestazione in alcuni esempi del Carnevale in

Sardegna [Power and ideology: spectacle and contestation in some examples of the Carnival in Sardinia]. Studi sardi XXIV: 593-625.

Atzori, M. 1988. Cavalli e feste. Tradizioni equestri della Sardegna [Horses and parties. Equestrian traditions of Sardinia]. Sassari: L'Asfodelo.

Atzori, M. 1997. Tradizioni popolari della Sardegna. Identità e beni culturali [Popular traditions of

Sardinia. Identity and cultural heritage]. Sassari: Edes. 
Atzori, M., L. Orrù, P. Piquereddu, and M.M. Satta. 1989. Il Carnevale in Sardegna [The Carnival in Sardinia]. Cagliari: 2D Editrice Mediterranea.

Bachtin, M. 1979. L'opera di Rabelais e la cultura popolare [Rabelais's work and popular culture]. Turin: Einaudi.

Baroja Caro, J. 1989. Il Carnevale [The Carnival]. Genova: Il Melangolo.

Bonato, L. 2006. Tutti in festa. Antropologia della cerimonialità [All in celebration. Anthropology of ceremoniality]. Milan: Franco Angeli.

Bravo, G.L. 2003. Orso e capra a nuova vita [Bear and goat to new life]. In Bestie, santi, divinità. Maschere animali dell'Europa tradizionale [Beasts, saints, divinities. Animal masks of traditional Europe], edited by P. Grimaldi, 35-43. Turin: Museo Nazionale della Montagna.

Broccolini, A., Ballacchino, K. 2016, (eds.). Carnevali del XXI secolo[Carnivals of the 21st century]. Archivio di Etnografia numero monografico 1-2 (a.XI).

Buttitta, A. 1996. Dei segni e dei miti. Una introduzione alla antropologia simbolica [Of signs and myths. An introduction to symbolic anthropology]. Palermo: Sellerio.

Buttitta, I.E. 2010. Carnevali di Sicilia fra tradizione e innovazione [Carnivals of Sicily between tradition and innovation]. In Il Carnevale e il Mediterraneo [The Carnival and the Mediterranean], edited by P. Sisto, P. Totaro, 206-248. Bari: Progedit.

Castelli, F., and P.Grimaldi (ed.). 1997. Maschere e corpi. Tempi e luoghi del Carnevale [Masks and bodies. Times and places of the Carnival]. Rome: Meltemi.

Castelli, F.,and P. Grimaldi (eds.). 1999. Maschere e corpi. Percorsi e ricerche sul Carnevale [Masks and bodies. Itineraries and research on Carnival]. Alessandria: Edizioni dell'Orso.

Clemente, P. 1997. Più feste, più vere. Riflessioni addosso a "Carnevale senza Quaresima..." di Fabio Mugnaini [More parties, more real. Reflections on "Carnival without Lent ..." by Fabio Mugnaini]. In Maschere e corpi. Tempi e luoghi del Carnevale [Masks and bodies. Times and places of the Carnival], edited by F. Castelli, P. Grimaldi, 95-102. Rome: Meltemi.

Della Maria, G. 1958a. Viaggio in Barbagia lungo le vie del folklore [Journey to Barbagia along the streets of folklore]. L'Unione Sarda» 26 August 1958.

Della Maria, G. 1958b. Le maschere della Barbagia residui di un'era lontana [The Barbagia masks from a distant era]. L'Unione Sarda» October 19, 1958.

Della Maria, G. 1959. Maschere antichissime nel carnevale di Ottana [Ancient masks in the Ottana carnival]. L'Unione Sarda February 15, 1959.

Gallini, C. 1977. Tradizioni sarde e miti d'oggi. Dinamiche culturali e scontri di classe [Sardinian traditions and myths of today. Cultural dynamics and class clashes]. Cagliari: Edes.

Grimaldi, P. (ed.) 2001. Le spade della vita e della morte. Danze armate in Piemonte [The swords of life and death. Armed dances in Piedmont]. Turin: Omega.

Grimaldi, P. (ed.) 2003. Bestie, santi, divinità. Maschere animali dell'Europa tradizionale [Beasts, saints, divinities. Animal masks of traditional Europe]. Turin: Museo Nazionale della Montagna.

Grimaldi, P. 2012. Cibo e rito. Il gesto e la parola nell'alimentazione tradizionale [Food and ritual. The gesture and the word in traditional food]. Palermo: Sellerio.

Kezich, G. 2015. Carnevale re d'Europa. Viaggio antropologico nelle mascherate d'inverno [Carnival King of Europe. Anthropological journey in the winter masquerades]. Scarmagno: Priuli \& Verlucca.

Kezich, G. 2019. Carnevale. La festa del mondo [Carnival. The feast of the world]. Rome; Bari: Laterza.

Le Roy Ladurie, E., 1981. Il Carnevale di Romens [The Carnival of Romens]. Milan: Rizzoli.

Mannia, S. 2017a. (Ed.). Oltre carnevale. Maschere, travestimenti, inversioni [Beyond carnival. Masks, disguises, inversions]. Palermo: Fondazione Ignazio Buttitta.

Mannia, S. 2017b. Al gran galà delle maschere. Considerazioni sulle pratiche carnevalesche nella Sardegna contemporanea [At the grand gala of masks. Considerations on carnival practices in contemporary Sardinia]. Oltre carnevale. Maschere, travestimenti, inversioni [Beyond carnival. Masks, disguises, inversions], edited by S. Mannia, 119-151. Palermo: Fondazione Ignazio Buttitta. 
Mannia, S. 2020. Politiche, potere, contestazione nei carnevali della Sardegna del terzo millennio: su battileddu di Lula [Politics, power, protest in the carnivals of Sardinia in the third millennium: su battileddu di Lula]. Studi offerti a Mario Atzori. Etnografie in dialogo: curiosità e passioni [Studies offered to Mario Atzori. Ethnographies in dialogue: curiosities and passions], edited by S. Mannia, G. Saba, 186-193. Sassari: Carlo Delfino.

Marchi, R. 1951. Le maschere barbaricine [The barbarian masks]. Il Ponte 9-10: 1354-1361.

Marchi, R. 1979. I “ciechi” di Orotelli [The "blind” of Orotelli]. La Nuova Sardegna February 25, 1979.

Masala, F. 1955. Dietro le tragiche maschere dei Mammuthones l'eterna prigionia del popolo sardo [Behind the tragic masks of the Mammuthones, the eternal imprisonment of the Sardinian people]. L'Unione Sarda» March 5, 1955.

Masala, F. 1984. Il riso sardonico [Sardonic rice]. Cagliari: Gia Editrice.

Masala, F. 1987. Storia del teatro sardo [History of the Sardinian theater].Cagliari: Alfa Editrice.

Masala, M. 1971. Il simbolismo dei "mamuthones" di Mamoiada [The symbolism of the "mamuthones" of Mamoiada]. Frontiera IV(2): 578-582.

Massajoli, P. 1972. I Mamutones [The Mamutones]. L'Universo LII (4): 777-794.

Massajoli, P. 1974. Le maschere di Ottana [The masks of Ottana]. L'Universo LIV (3-4): 471-490.

Merche, S. 1986. Folklore Sardo-Orotellese [Sardinian-Orotellese folklore]. Nuoro: Arti grafiche AR.P.E.F.

Mirizzi, F. 2012 Per un repertorio delle maschere meridionali tra carnevali vissuti e carnevali della memoria[For a repertoire of southern masks between lived carnivals and carnivals of memory]. In La maschera e il corpo [The Mask and the Body], edited by P. Sisto, P. Totaro, 109-123. Bari: Progedit.

Moretti, P. 1954. Mamutones e maimones [Mamutones e maimones]. Lares XX (3-4): 179-180.

Moretti, P. 1963. La mascherata dell'orso in Sardegna e il significato dei «Mamuthones» [The masquerade of the bear in Sardinia and the meaning of the «Mamuthones»]. Nuovo Bollettino Bibliografico Sardo e Archivio Tradizioni Popolari VIII (43-44): 3-4.

Moretti, P. 1967. La maschera dell'orso nel carnevale sardo [The bear mask in the Sardinian carnival]. Lares XXXIII (1-2): 23-31.

Nurra, P. 1896. Nella Barbagia settentrionale. Impressioni di viaggio [In northern Barbagia. Travel impressions]. Sassari: Prem. Stab. Tip. G. Dessì.

Orru, L. 1999. Maschere e doni, musiche e balli. Carnevale in Sardegna [Masks and gifts, music and dances. Carnival in Sardinia]. Cagliari: Cuec.

Pillonca, P. 1981. Dopo quarant'anni ritornano «sos thurpos» [After forty years «sos thurpos» return]. La Nuova Sardegna February 27, 1981.

Rossi, A., and R. De Simone. 1977. Carnevale si chiamava Vincenzo. Rituali di Carnevale in Campania [Carnival was called Vincenzo. Carnival rituals in Campania]. Rome: De Luca Editore.

Satta, M.M. 1982. Riso e pianto nella cultura popolare. Feste e tradizioni sarde [Laughter and tears in popular culture. Sardinian festivals and traditions]. Sassari: L'Asfodelo.

Sisto, P., and P. Totaro (eds.). 2010. Il Carnevale e il Mediterraneo [Carnival and the Mediterranean]. Bari: Progedit.

Sisto, P., and P. Totaro (eds.). 2014. La maschera e il potere [The mask and the power]. Bari: Progedit.

Sordi, I. (ed.). 1982. Interpretazioni del Carnevale [Interpretations of the Carnival]. La ricerca folklorica numero monografico 6.

Sordi, I. 1993. Il carnevale di Ottana e le sue maschere, in Alle radici del teatro (a cura del Centro teatrale S'Arza) [The Ottana carnival and its masks, in At the roots of the theater (edited by the S'Arza Theater Center)], 29-40. Sassari: Gallizzi.

Spera, V.M. 2004. Il sarmento e l'edera. Metamorfosi di un carnevale contadino. Le "propaggini" di Putignano fra arcaismo e televisione [The sarment and the ivy. Metamorphosis of a peasant carnival. The "offshoots" of Putignano between archaism and television]. Perugia: Gramma Edizioni. 
Testa, A. 2014. Il carnevale dell'uomo-animale. Le dimensioni storiche e socio-culturali di una festa appenninica [The man-animal carnival. The historical and socio-cultural dimensions of an Apennine festival]. Naples: Loffredo editore.

Toschi, P. 1955. Le origini del teatro italiano [The origins of the Italian theater]. Turin: Einaudi.

Манниа, Себастиано*

\section{Маски и карнавалы в современной Сардинии}

DOI: $10.33876 / 2311-0546 / 2020-52-4 / 29-44$

Карнавал занимает важное место в культурной жизни Сардинии и привлекает внимание ученых в силу постоянно обновляющихся значений и функиий. Более того, институт карнавала относится к числу культурных акций, обладающих большим потенциалом влияния на существование локальных, спонтанно возникающих в его контексте групп активистов и культурных объединений, деятельность которых в свете карнавала активизируется, перепрофилируется, меняется: местные традиции переосмысливаются и приобретают новое звучание наряду со специфическими идентичностями и новыми формами выражения. В этом смысле можно говорить о новых карнавалах и о новом звучании культурного наследия в изменившихся экономических и сочиальных контекстах. Иными словами, сегоднямние образы и маски в русле современных потребностей и запросов общества отсылают к некой не исторически бытовавщей, но искусственно созданной, вымышленной традиции. Сардинские карнавалы являются наглядным примером тех спонтанных, эндогенных настроений и процессов, которые рождаются в современном локальном соииуме прежде всего с иелью удовлетворения «идентификационных потребностей». Это приводит к акцентированию, восстановлению, «вторичной подаче» и изменению ряда элементов традиции. Автор статьи пытается осмыслить отмеченный комплекс вопросов, подчеркнуть сложность и многогранность карнавального феномена на Сардинии.

Ключевые слова: маски, карнавал, культурное наследие, Сардиния

* Манниа, Себастиано - профессор культурной антропологии, этнологии и методологии антропологических исследований, департамент истории, гуманитарных исследований и образования, Университет Сассари (07100 Италия, Сассари, Виа Занфарино 62). Эл. почта: smannia1@uniss.it. 